\title{
The Image of Indigenous Peoples of Siberia in D.I. Karatanov Creative Work
}

\author{
Maia G. Smolina* \\ Siberian Federal University \\ 79 Svobodny, Krasnoyarsk, 660041, Russia
}

Received 15.07.2014, received in revised form 10.10.2014, accepted 01.12.2014

The subject of this article is the reflection of the Siberian indigenous people, the Kets (or so called "the Ostyaks") in works by D.I. Karatanov. The aim of the research is achieved by analysis of individual features of these works - portraits, landscapes and many-figured scenes of everyday life. In this research were used such methods as structural and semantic analysis of art works, revelation and analysis of main compositional patterns, consideration of immanation and emanation parts of an artistic image. Following the results of the research, work plays the role of a fore-praying to the nature in the life of Kets fishermen. The result can be used in art sphere of the Krasnoyarsk Territory, history and culture of the Siberian Region and in researches dedicated to national and cultural identity.

Keywords: Kratanov, Surikov, pictures, the Ostyaks, the Kets, work, fishing, the North, Siberia, Krasnoyarsk, composition, emanation, indigenous peoples, ethnography, expedition.

Research area: art history.

\section{Introduction}

Dmitry Innokentyevich Karatanov (1874-1952) is a famous artist of the Krasnoyarsk Territory and his role in Siberian art can be described by several aspects: 1) a leading teacher of the drawing school;

2) a regional ethnographer and historian;

3) an art descriptor of the local uniqueness;

4) a follower of art traditions posted by V. Surikov 5) a successor in the Russian landscape art tradition in the latter half of the $21^{\text {st }}$ century (landscape painting traditions peculiar to Karatanov's works are art approaches used by A.K. Savrasov, F. Vasilyeva, I.I. Levitan and A.I. Kuindzhi); 6) a drawer with individual graphics and design.
Settled facts in Karatanov's biography make the research of his works especially important in the context of anthropology, Siberian ethnography and regional history. The drawer was born in the village called Askiz, Khakassia. His father was an author of the ethnography work (the Tatars of Minusinsk), so the interest in ethnography devolved to his son. M.A. Rutchenko and V.I. Surikov as masters asserted their influence over Karatanov's works and his decision to become a drawer. After his graduation from St.Petersburg Academy of Arts Dmitry Innokentyevich made his art debut in Krasnoyarsk by painting churches. $\mathrm{He}$ also worked in the workshop belonging to M. Tenisheva - famous Russian princess, well known for her favor to folk craft and decorative

(C) Siberian Federal University. All rights reserved

* Corresponding author E-mail address: smomg@yandex.ru 
and applied arts. Together with another artist V.A. Serov, D. Karatanov created stage sets. On his return to Krasnoyarsk, the drawer began teaching in drawing school founded by V. I. Surikov, where soon he became a leading teacher. During the Revolution Karatanov worked in Krasnoyarsk Regional Museum and as a member of ethnographic expedition visited places in the lower reach of the Yenisey, Far North regions, the Middle Yenisey and the $\mathrm{Ob}$, creating the pictures depicting the life of indigenous North peoples in Siberia.

Comparatively small number of researches are dedicated to D.I. Karatanov's art. Among them we can mention the works of I.M. Davydenko, P. N. Meshalkin, N.V. Lisovsky, T.M. Lomanova, M.V. Moskalyuk, T.V. Ryannel, A.L. Yarovskoy. A.A. Semyonova and A.V. Baraklova in their article mention about Karatanov's within visual representation of the concept of north. Still as for Karatanov's pictures and graphic works, so no research considering the relationship between a siberian person, their natural environment and cultural and everyday life was presented as well as a staged comparison of his works with V. Surikov's works, though a lot was said concerning their connection. Whereas analysis of Karatanov's art works is important for understanding the distinctiveness of the local art school in XX century, cases concerning indigenous peoples of Siberia and North Siberian regions in particular are of vital importance for modern researchers and humanitarians.

\section{Methodology}

This article deals with challenge in study of Krasnoyarsk art in the first half of XX century. The criterion of relations between a person and art work space is one of the most effective means of analysis in art studies by the theory of visual thinking mentioned in works of V.I. Zhukovsky. The aspect of visual compositional archetype in culture was developed in architecture by N.L. Pavlov and its central points might be extended on painting and graphics. Within this research the main focus was brought to the view of diagonal compositions in art semantics suggested by N.M. Tarabukin, a member of the Tartu-Moscow Semiotic School. To determine an inside content of works by D.I. Karatanov it is essential to consider researchers dedicated to folklore of Kets (i.e. works by E.A. Alekseenko and A.V. Golovnev) and also materials on North Culture collected by V.I. Anuchin. Having recognized works of an outstanding Siberian artist Dmitry Karatanov as a representative for local art tradition of 1920-1930, we would analyze painting and graphic pieces of art with respect to interrelationship between a viewer and the art space, thus showing and evaluating the criterion mentioned above.

\section{Specific Features of D.I. Karatanov's Creative Works}

The body of works by D. Karatanov who was not only a drawer with his individual graphics and design approaches, but also a landscape painter, portrayer of everyday life, ethnographer, artist and the first teacher in the first Siberian art school, is not merely informative but also impressive and catching. It means that engaging in the art space created by the artist, a viewer has an opportunity to experience an extreme, or severe and alien space, to become a part of a hostile world as it might be at the first time, to feel "some" new relation to their life or to experience a sort of catharsis from recognizing themselves in non self space. Many of his works lay a strong condition on viewers: do or die. Rather than ease one's energy or attract by charm of exotic places, these works set a person for an active position by taking them into unfamiliar space and putting in front of the most important problems of life. Thanks to biographical facts and memories of 
the artist about artist meetings with V. Surikov, D. Karatanov has been recognized as Surikov's follower in art. Nevertheless, by considering the most representative landscape pictures, portraits and everyday life scenes, we should pay our attention not only to general realistic style of their works, but also to the individuality in art pieces by D. Karatanov.

By taking landscape genre the artist do not use epic panoramas peculiar to Siberian landscape pictures by V. Surikov where the nature resembles scenery for historical events. Karatanov's point of view on the space might be diverse, though quite often it is represented by nature scenes created inside the space as an active participant and not a simple observer. For example, riverscapes of the artist are usually painted from the water "inside" and taken from viewpoint of a vision object included in the space, i.e. a person being just in the water, or as a variant, on a boat. Woodland scenes are described from an outlandish area where the object cannot even see the sky covered by branches. The scenes of Stolby pictured by D. Karatanov are accompanied by the theme of human friendly relations and that also interprets the natural space as a place for warm hearted talks.

By analysing portraits of Ostyaks one becomes sure that the artist as well as V. Surikov, was really good at psychology and had a knack for depicting ethnic psychology choosing the right view, lightening, volume and space interpretation, gestures and facial expressions. The difference lies not in approaches but in the subject of interest of these two artists, i.e. in those personal features they attempted to outline: while V. Surikov marks such characteristics of Siberian people as bravery and boldness, D. Karatanov prefer isolated persons or loners among the Ostyaks, their humility before Gods, mysterious aloofness and distance. V.I. Surikov worked on those facial features of the Khakas ans Cossacks which were appropriate for his grand historical pictures where as a rule martial and fight-back spirits are imaged. For the picture called "Krasnoyarsk Rebellion" in the same manner as for "Conquest of Siberia by Yermak" V. Surikov was in a steady search for types of face and gained experience in portraying demonstration of rebellion and resistance. For example, the portrait of a Khakas woman (1909) which is now belonged to Vasily Surikov's Estate Museum, contains such intensive details of a woman appearance as a kerchief tied out of straight what was out of cloth traditions and added some special power to this woman, or a small golden cross against folk dress of the Khakas as a symbol of Christianization. While creating the portrait of an Ostyak shaman woman "Ostyak Woman (Shaman Woman)", it was important for the artist to not to focus on voodoo details, and that was not due to poor shaman appearance among a number of the Ostyak groups (Fig. 1).

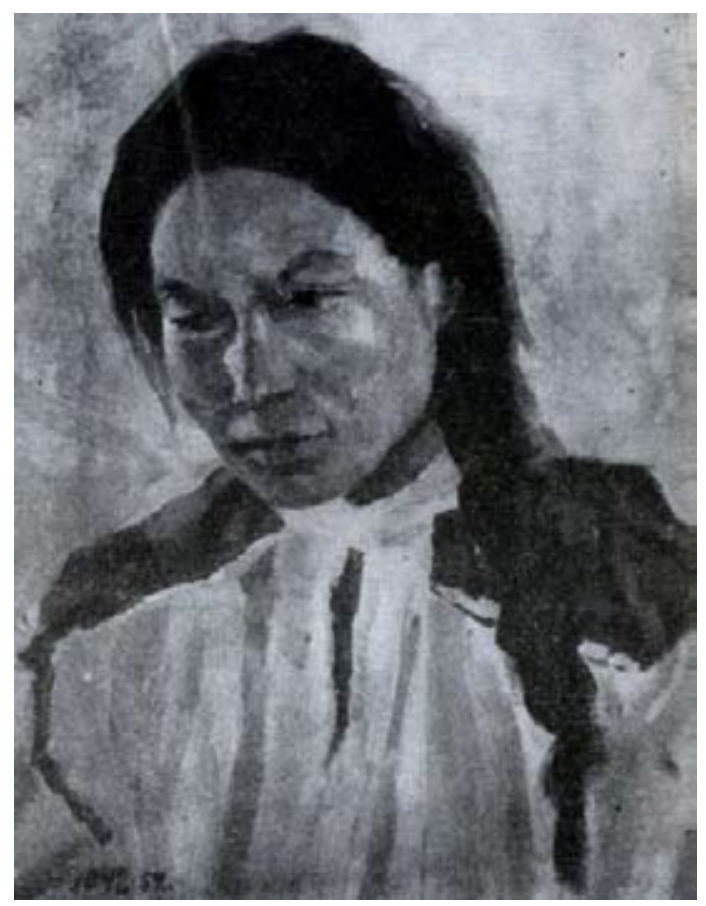

Fig. 1. Ostyak Woman (Shaman Woman), 1906. Canvas. Oil. The Russian Museum of Ethnography, Moscow 


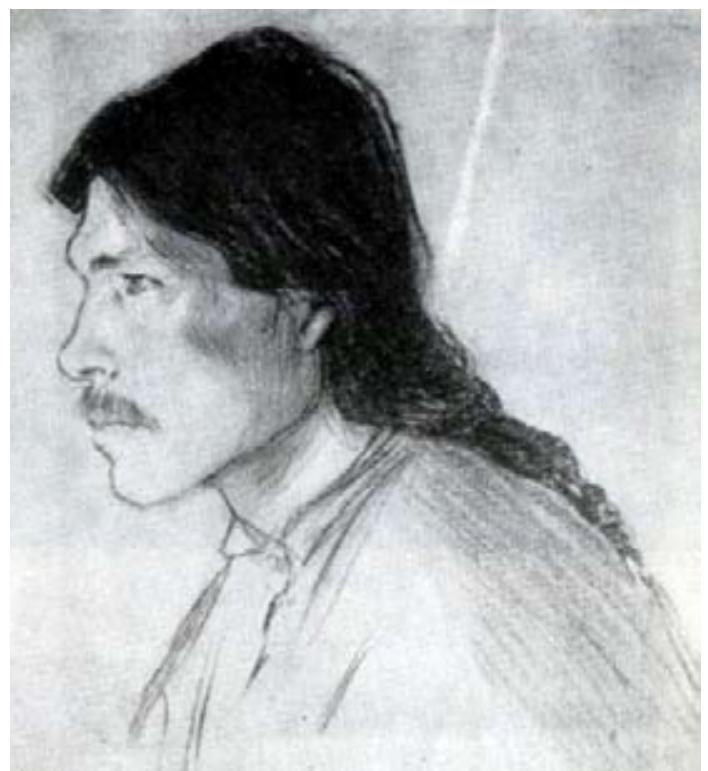

Fig. 2. Ostyak Man with a Scythe. Pencil. 1906. Canvas. Oil. The Russian Museum of Ethnography, Moscow

General lines of this woman are flowing and free; lines stretched from the bottom upwards dominate: she has her head kept down, flowing hair, half-closed eyes and a secret smile. The portrait of a Ostyak man called ("Ostyak in Chum”,1906) is made in side-face, i.e. his face is turned to the light which creates the volume of his head and his hair obediently falls on his shoulders. It seems that the light with all its energy passes through this man. It might be said in some way that most of characters made by D. Karatanov are self-sacrificed people who refuse the spirit of rebellion: they deeply blend into the nature and feel every piece of her beat (Fig. 2).

Whereas Surikov's ethnographic drawings of the Khakas lifestyle reflect hobbling, hunt equipment or a clapped in irons criminal, or in other words while the artist is interested in the phenomenon of an active male principle in the image of Siberian indigenous peoples, D. Karatanov pay his attention to principles of work solidarity and harmony with the nature. This explains many patterns of his pictures where characters are quite similar to each other: together they step by step land boats, ritually and routinely dry fishing nets or a character who is fully concentrated on fixing his seine. Though some distance perception of indigenous peoples these pictures give a feeling of wonder and acceptance of their humility in work. Thanks to the change from a pure scientific analysis of indigenous peoples lifestyle to a moment of catartic understanding of universal concepts which temporally give a common ground to so called "we" and "they", works of this drawer are full of artistic importance.

Actuality of D. Karatanov's pieces of art is expressed in the way that he does not use academic schemes, rules or methods of composition. The artist believed that there was nothing to develop artificially since Siberian nature had already created the composition. If we use terms from the sphere of phototechnics, we say about image framing method in which searching for the right frame is the main artistic mean. Nevertheless, N.V. Lisovsky suggests, that despite seeming simplicity, Karatanov's works contain only those details and elements that do not prevent from a clear perception.

Hard and cold landscape pictures by D. Karatanov rarely show people, but if they do so with no prevalence over the nature.

As a comparison with another famous Russian artist V.I. Surikov, who was also the founder of the art school in Krasnoyarsk, we suggest analyzing his landscape work "Yenisey near Krasnoyarsk" (1909) belonging to impressionist realism. The Yenisey is shown here diagonalically in accordance with the demonstration diagonal. This method V. Surikov used in many other landscape pictures of Krasnoyarsk. Rather, Karatanov's pictures are based on a diagonal going from a viewer, which is characterized by the spirit of breaks and typical for a new artistic generation of the 
Early Soviet period. Besides, D. Karatanov avoid using panoramic thinking and epic scenes peculiar to V. Surikov's works. He is rather keen on mysterious, hidden places, quit river banks or smooth water surface. Such diagonal composition is represented in his riverscape work called "Laryak. The Bank of the Vakh River". "Yenisey. Last Ice" and "Laryak" are both pictures with a fighting diagonal (as it is suggested by N.M. Tarabukin) which means a slow rising. That hard but active ascent is a kind of criteria for communication with severe Siberian areas showed in Karatanov's works (Fig. 3).

The solution of the problem concerning a person and space in D. Karatanov's landscape pictures is that the artist always views from the position of human abilities in this world. The master concentrates in his works on the human side ("my abilities") rather than on the objective reality in attitude to the living. In pictures of taiga and the Stolby he chooses such an amazing sight point that is appropriate for a viewer - not a bird's eye panorama. Among other examples there are pictures called "Taiga" and "Summer Day in the Stolby" (1909). Still if we take the later works of D. Karatanov dedicated to the Stolby in summer time (1930), we will see good relationship between people and the art space, sky or most convenient ways of people-space communication. Two persons sitting in two different rocks create a dialog, a free conversation both with each other and the nature. There is a sort of virtual ladder to the sky with grand steps represented by huge rocks. Still, these steps are in power of giants: they require superhuman capabilities and efforts and thus arranged in a crossing diagonal. A flying bird in the sky expresses an image of freedom and liberation from physical gravity (Fig. 4).

Later in the picture called "The Stolby in Winter" (1951) the relationship between people and the sky are mostly open. A tree in this picture symbolizes a ladder to the sky. Feeling

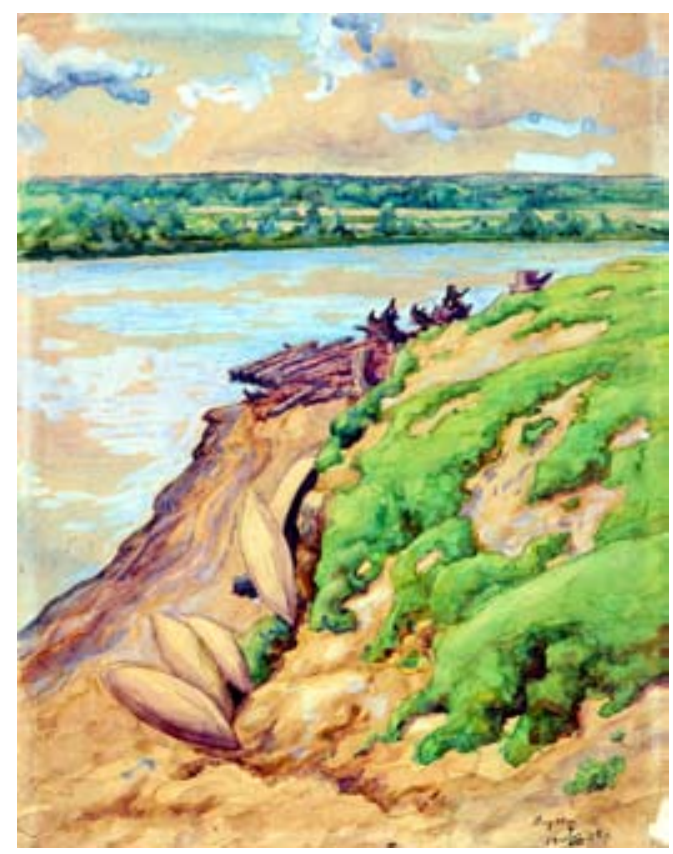

Fig. 3. Laryak. The Bank of the Vakh River. 47.5x37.0 sm; Paper, Watercolour. Vasily Surikov's Art Museum, Krasnoyarsk 


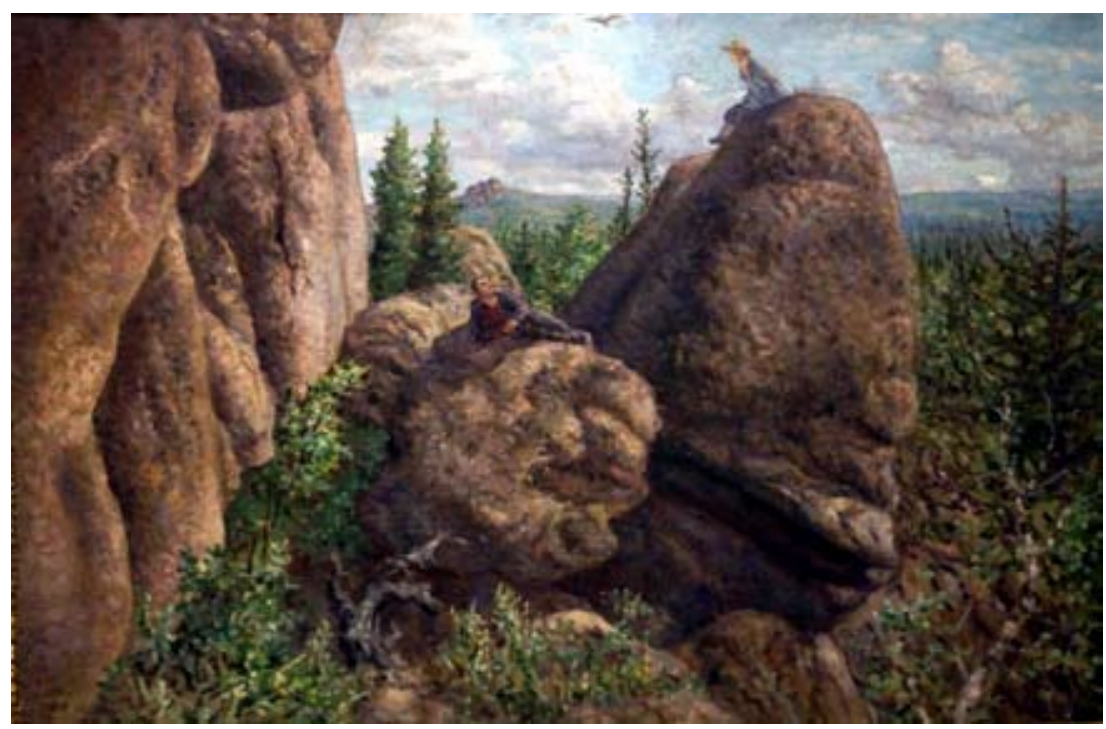

Fig. 4. The Stolby in Summer Time. 1930. Krasnoyarsk Regional Museum

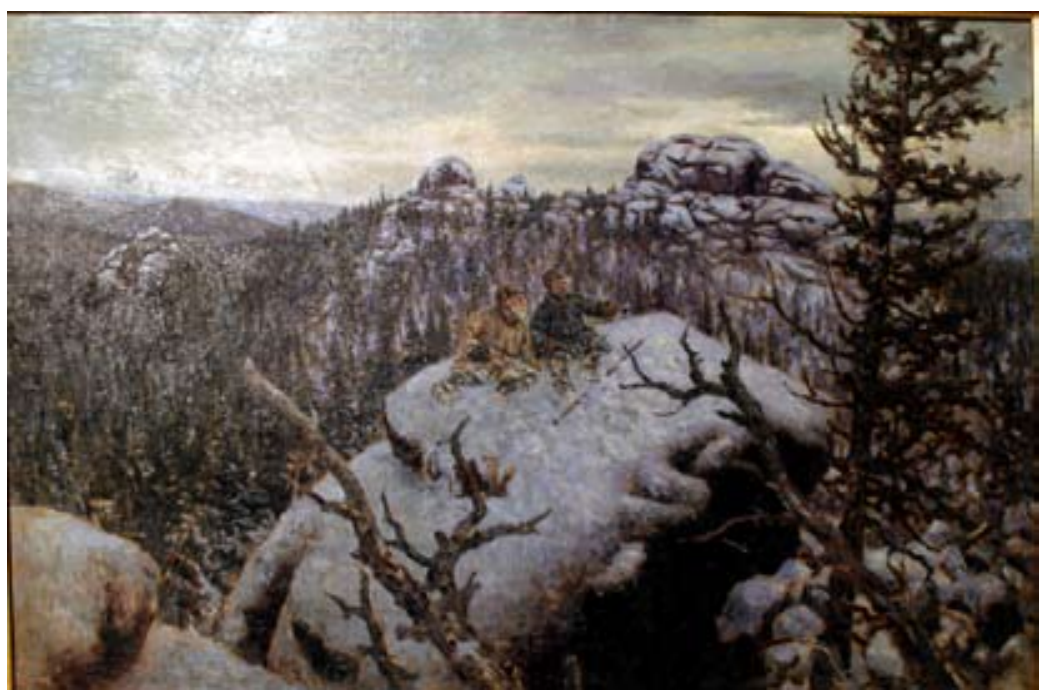

Fig. 5. The Stolby in Winter. 1951. Krasnoyarsk Regional Museum

of freedom and greatness is created due to a panoramic view from the high sight point. Two small men on a gigantic rock outlines the real role of a person in the entity. D. Karatanov always tried not to hyperbolize this role but to engage a person into the reality and catch this organic refinement. There is no collision of solitude in this picture but it has literally brightened by the snow phenomenon of that harmony (Fig. 5).

\section{Features of Many-figured}

Scenes Composition

in D.I. Karatanov's Creative Works.

Many-figured everyday scenes in pictures and graphics made by D. Karatanov are divided in two types: centric composition and detailed scenes.

Centric compositions includes scenes of Ostyak gatherings such as a common meal or 
talk (e.g. "Rest in Yurt. Talk", "Meal"). In these drawings a concentration of personal soul energy based on the same rhythm of life takes the front position. Talks and rest are the thing which we call a rhythmic organization of life and a dialectical opposition to work stress. The drawing called "Meal" (paper, pencil, 36x50 sm, 1928) represents a many-figured scene in a house of Kets. Ostyak men sit at a small table and take food. The head of the family sits in the very center of the drawing at the point of diagonal intersection. The family resemble a unified whole, every member of it is similar to the other in position and form. It is interesting that such consonance is outlined by breaking lines which keep excitement and trepidation, or in other words, that pulse of life featured to the consciousness of indigenous peoples.

A specific combination of counterpoints and rhythmic connection of scenes in pictures is a distinctive pattern of detailed many-figured compositions. Scenes repeat each other like an echo and create a sort of ornamental design with variations for one rapport. This principle of repeat is quite often used in folklore, poetry, pieces of music and thus familiar in art. The artist used rotational symmetry of figures to recreate a common beat of working ritual. These visual repeats symbolise rhythms of the nature and natural calendar which characterize the pagan culture. The composition in D. Karatanov's pictures is built in such a way that some characters doing their everyday activities are depicted in the closest to a viewer part of the work that one can not see their legs, and other figures are showed in the middle or long distance. Such counterpoint composition is interesting in the context that scenes are symmetrical to each other. This means that figured which are drawn on the front almost echoes middle distance figures in the way of positions (their bodies are tuned to another side). This point of interest creates the lifestyle rhythm: there is a routine and narrative chronotope, i.e. an artistic time and space which determine the reality as an infinity repeated day by day, steady feeling of time coming a full circle and involving into the phenomenon of space. The impression of sequence development of a working process is a kind of a rhythm in life. In the drawing "Ostyaks in Small Izba" on the front we see a man sitting in the full-back position, then in the middle another man who sits in the front-face position and his figure is cut off by the border of the picture. These two men are round-shouldered, their heads are kept down, faces and hands are of a quite large size. All the characters are similar to each other: there is a common rhythm in gestures and positions with little variations. In such a manner a turning around effect is made: their bodies are turned and express not just a moment but the whole process of working, their silent ritual which remains some endless smooth melody.

As an example of this combination we mention "Nansen's Expedition", "Ostyaks Settlement", "Hunters", "North Faces". By drawing identical characters the artist creates an impression of people as a whole entity. Showing a figure now in full-face then in half-face, the master forms a kind of ornamentation of humanlike figures.

The drawing called "Kets Fishermen" has on its front a figure of man cut by the edge. The man is depicted closely to a viewer zone creating by that a closeup. The same man one can see in the middle distance but he sits in the full-back position. It creates an effect of a staged involvement of the viewer into the process, an impression of turning around: bodies of these fishermen are turned in the way that interprets the whole process of their activity, its length and rules.

Arched lines of their fishing nets are also distinctive details of the picture. These lines rises up as the Kets handle this equipment as if stretching it. Yet it might be concerned as an appeal to the heaven, a ritual of praying for a fine 
catch of fish which symbolizes a heaven gift. That is what a fisherman asks the God for by showing self-sacrifice in his work. Such an interpretation of the picture is possible due to the concept and practice in art science which are connected with the theory of emanation and immanation principles in art works (they are mentioned by V.I. Zhukovsky).

V.I. Mashkov noticed that D. Karatanov drew hands misfitted in size. "You drew this face very well, but underworked hands. They are the detail that can tell us a lot", he explained to students. This misfit in the size is made in order to draw one's attention. He also suggested catching the way a person put their feet since he knew a relation between walking and a person's appearance. These round back figures are attractive and express not only physical features of these men but also their inside condition.

The same method is used in "Fishermen" (1927). Though fishermen showed in the front and middle positions perform different stages of their work, their figures coincide in a bend of their heads: lines here are almost merged with their rounded shoulders. D. Karatanov practiced that method to introduce viewers into the working space, into the reality of a fisherman. We stand behind two fisherman revising their nets and see fish there, then cast our minds to another man sitting on the very river bank and scaling fish. There is one more character who standing at some distance watches the work process. This is another alternative for the viewer to let him find a place virtually being in these extreme conditions (Fig. 6).

Considering D. Karatanov's works dated in the period of 1930-1940, we mark the fact that the drawer did not refuse that method of space construction. In his graphic work "Nansen's Expedition" (1936) the drawer in his individual way presents the rhythm by depicted dogs. Their positions are diverse but at the same time there is a repeat in standing and sitting figures showed in a full-back or full-face turn. In this way an impression of one and only depicted dog has been created. The same thing we say about men. In the close-up view we see a person looking through a measure instrument; in the middle distance another man handling the neck-piece of the fur coat and waiting for his turn to use that instrument; then in the long distance we notice two more men with dogs. There is a staged panorama of that

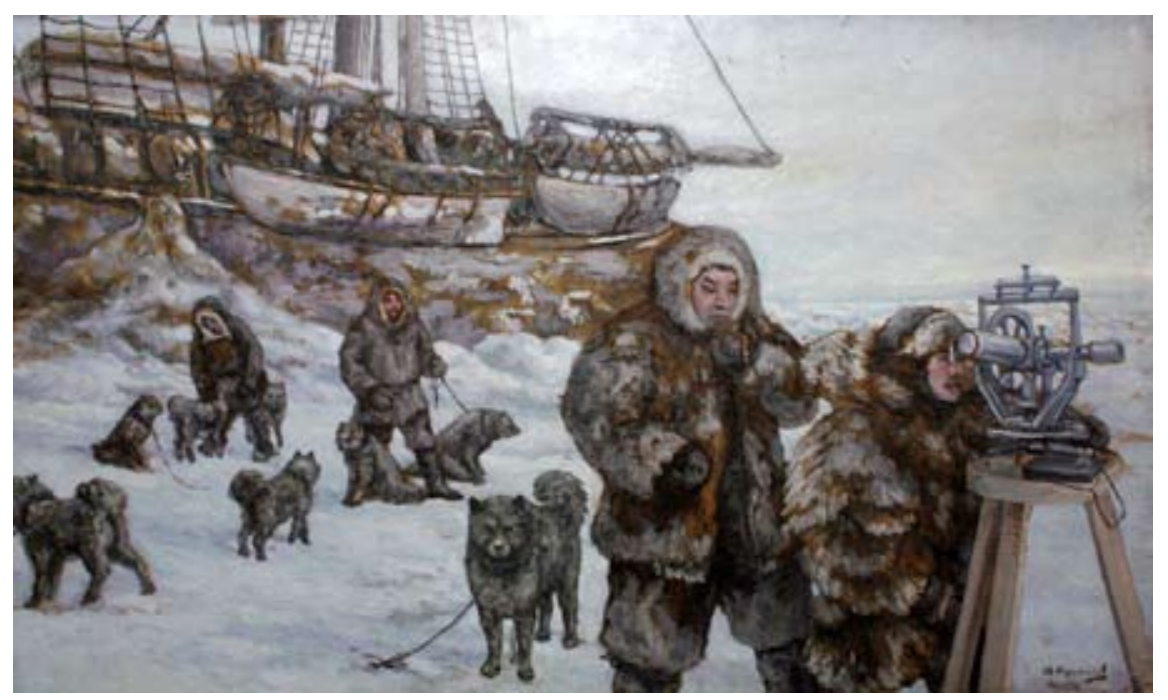

Fig. 6. Nansen's Expedition. 1936. Canvas. Oil. Krasnoyarsk Regional Museum 
scene. The activity is represented as a process showed from its inside: from relaxation and calm to tension and anticipation, and, finally, to discovering of new territories. Similar approach is used in "Hunters coming back" (1948), where characters are drawn going one after another in the space of winter forest. Each figure matches the right position creating a meeting between viewers and these walking men.

The detailed analysis of D. Karatanov's works which include a motive of work process with many-figured compositions, leads us to the conclusion that there is a number of common methods peculiar to the language of this artist despite the degree of developing indigenous peoples theme or showing the importance of work in general.

\section{The Reflection \\ of Indigenous Peoples Identity in the "Ostyak Pictures" Series by D.I. Karatanov}

In this part of the research we will analyze the Ostyak series of drawings made by the member of Krasnoyarsk Regional Museum of Local History and the drawer as a conceptual representation of indigenous peoples and their worldview. There is a lot of questions to be answered. Was D. Karatanov interested in working life in itself or was it a reflection of a mythological worldview? Was it based on the religion or, perhaps, it was just a ideological belief that work was the only thing separating a man from an animal? There is some common ground between held tight fishing nets, turned to the sky branches and tillers of cut trees in his pictures. Do these constant motives presented in the series of works shows a life drama of that indigenous people and endangered category of hardworking people?

The series was created when D. Karatanov for a ninth time participated in expedition to the Narymsk Territory located at the river $\mathrm{Ob}$ and its feeders the Vakh and Tym, in 1927 and 1928. His works describes indigenous peoples of Siberia the Ostyaks and the Voguls.

The drawer creates the most impressive pictures relying on initial expedition drafts and sketches made at papers with horizontal format but still he develops little more than a simple narration of indigenous life. Look at main vertical lines in these pictures: they pass through the sky like at praying so natural to them as working days for a man. In the work "Ostyak settlement in summer" and in the watercolour "Float made of dry branches" we notice that approach when branches and float parts stuck out the water. One more example of this method is presented in the previous art work "Stolby" ( or "Sombrous Spring") where the whole sky and rocks are covered by ugly sticks and branches of hungry and cold trees (Fig. 7).

In the work mentioned above we find something penetrated by a mythological worldview. Here, an eschatologic mind of Kets is put on the front position: the world will be destroyed by the flood, the earth will be drowned and all flesh will die. The center of a new world will be mud territories where on small dry points covered by forests few men will be take to life again. The development of the world from nonbeing resembles a birth of the earth while water and air stay forever. Initially the earth is of a small size but then it develops and broadens (Fig. 8).

This watercolour introduces us a meeting between a young man on a boat with an old Ostyak man sitting on a float made of dry branches at sunset. The young man depicted on the front position of the picture gets ahead the float and turns his face to the old man. They both wear traditional cloth of the Kets. The kerchief on the man's head is a part of his work cloth since it gives an opportunity to hear the nature what is necessary to hunters and fishermen and besides defends people from mosquitoes. 


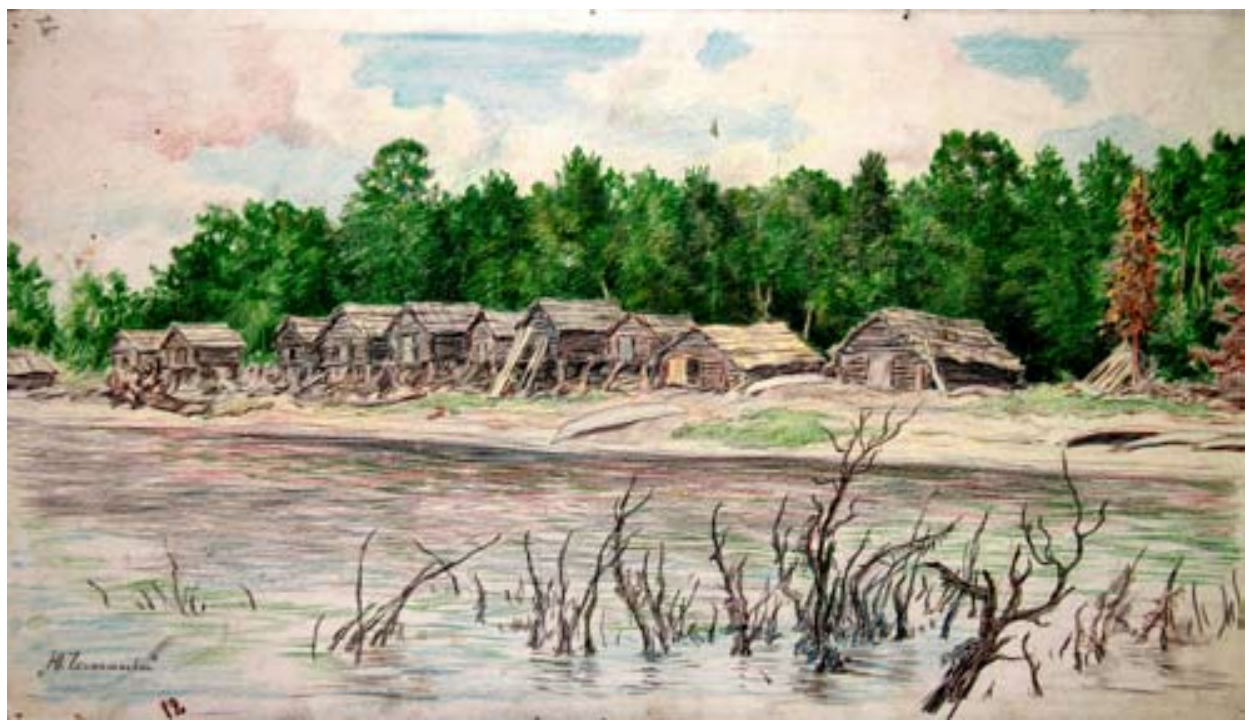

Fig. 7. Ostyak Settlement in Summer. 1928. 28.2x49.5. Paper. Colour pencil. Krasnoyarsk Regional Museum

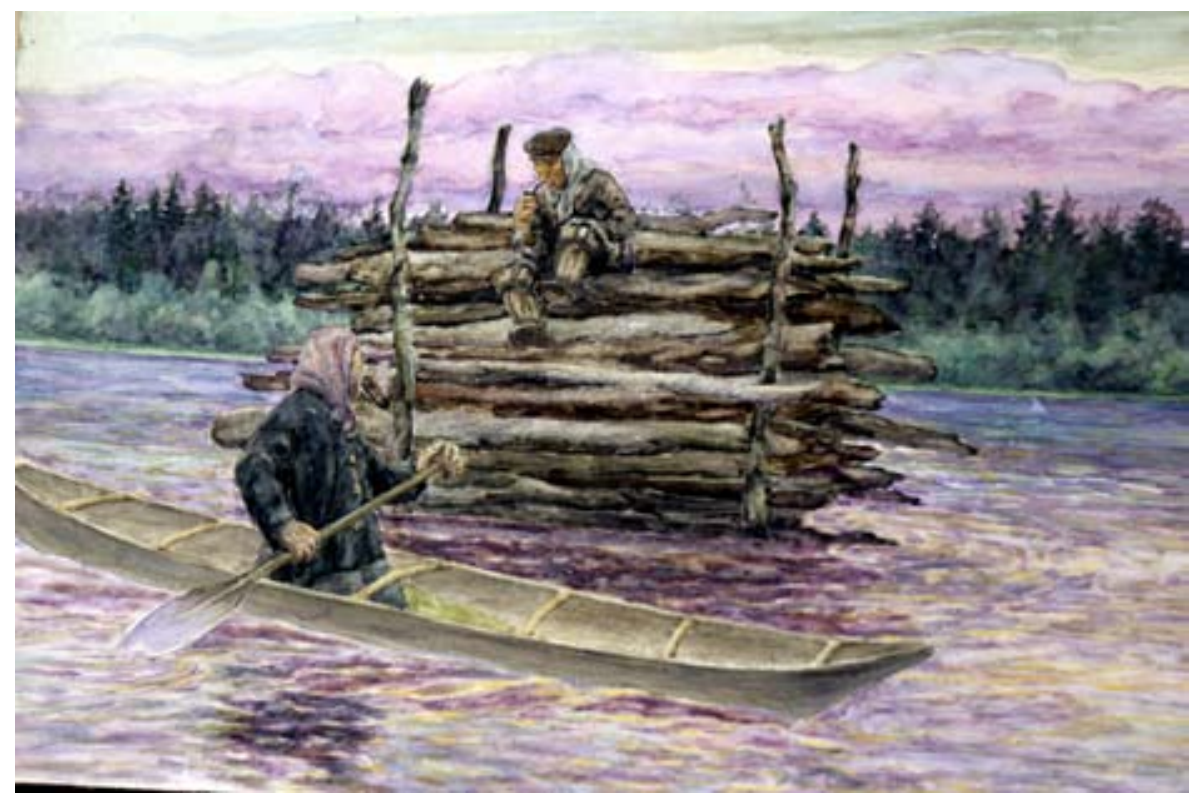

Fig. 8. Float Made of Dry Branches 28.5x65.0 sm. Cartoon. Watercolour. Krasnoyarsk Regional Museum

There is a draft to this watercolour. It has a sign which explains the composition: "Ostyak Ill with Tuberculosis". The drawing was an original task determining the view and positions of its characters (Fig. 9).

The watercoloured sunset in the "Float" sends us to mythos of the Kets. The Sun there is painted as a woman (or a woman of the Sun). According to the Khanty (on of the Ostyak peoples), long ago there only was a day: there was no sunset. But the God called Torum ordered the Sun to set to have people sleeping. Thus the sunset, on the one hand, is a time when people can have a rest after their work and a cultural symbol of manhood and 


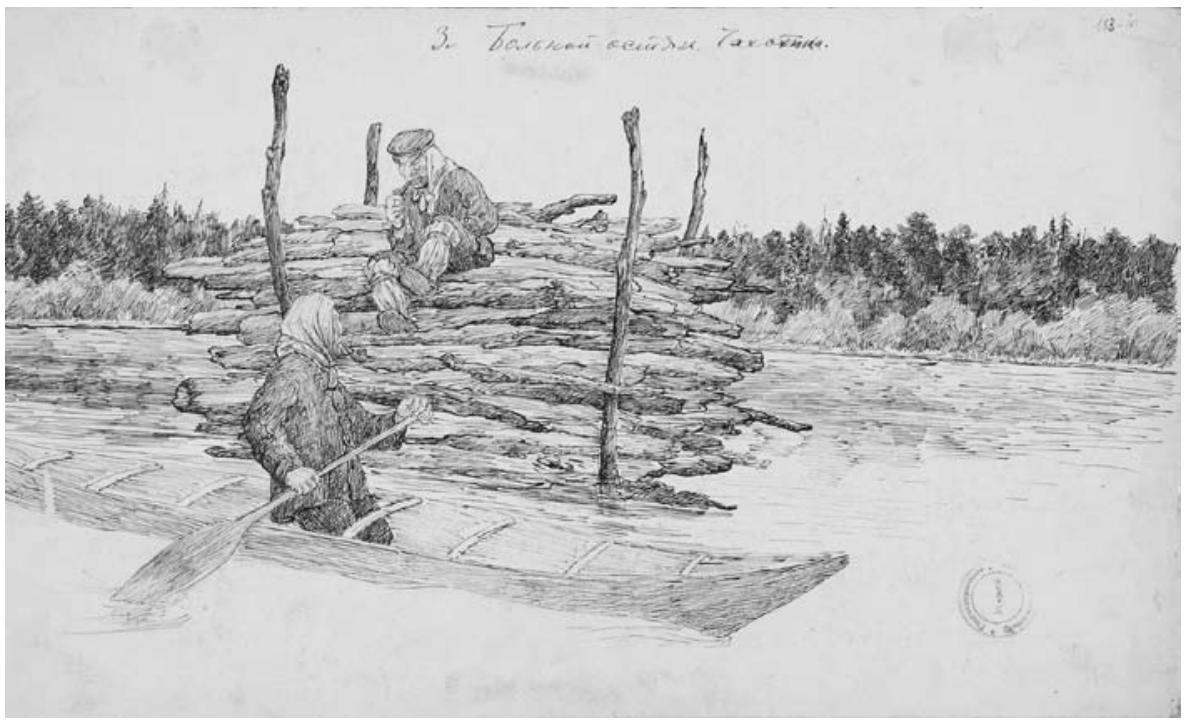

Fig. 9. “Ostyak Ill with Tuberculosis ”. 1928. 32.0.x52.5 sm. Cartoon. Drafting ink. Pen. Vasily Surikov's Art Museum, Krasnoyarsk

wisdom, on the other. The reflection of pink sun beans on the river surface is a wide goodness from the heaven touched by the young man. The dialog between the old and young generations is represented in the context of the sunset, and four vertical sticks turned to the sky refer to funerals showed in another Karatanov's work "Funerals in the Far North Regions". A.V. Golovnev in his research interpret the number "four" by funeral traditions of Ostyaks. All these aspects prove trepidity of the artist regarding the sunset of these indigenous peoples. The watercolour "Float made of dry branches" is far from a simple ethnographic material since it symbolizes the transformation scene from an everyday routine work to a meeting with a Fortune personified in that old and ill man. The moment of the recognition which is connected with the reveal of one's death (memento mori) takes place for the character whose face we can not see. This was a great artistic decision since one can not see our face when they suddenly feel the truth (Fig. 10).

This drawing is one of fascinating examples in Ostyak series. The work visually carries

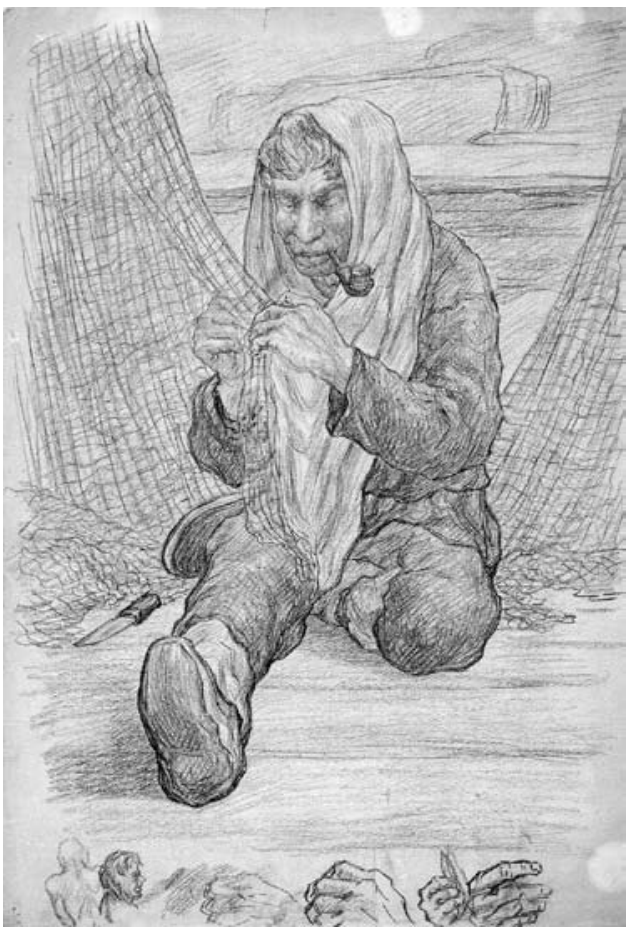

Fig. 10. Repairing the Seine. 1928. 53.5x36.5 sm. Cartoon. Pencil. Vasily Surikov's Art Museum, Krasnoyarsk 
the entire idea caught by the drawer. The idea concerns not only everyday life of people but also has a potential of going far beyond the description of the indigenous culture. In the center of the drawing we see a Ket man sitting on the wooden floor. Fishing nets hang down at both sides so as their lines continue the man's hands bent at the elbow. Such a position creates the general virtually presented line looking like an up-end arch considered as a feeling of goodness receiving. Good examples of this conception are seen in many architectural cultic works and called as "the bowl of chaotic water". According to the conception of altar system in churches suggested by N.L. Pavlov, that bowl is a cultural archetype and it can be used in arts. Still, there is a counter arch - an up-end bowl, i.e. a visual line determined by the main character: he keeps the head down, his kerchief also flows down creating emanational action, and his wavy figure contributes to the slip effect.

Thanks to that decision the artist manages to create a very impressive work where one can find a balance of contrasts and the state of the character's mind becomes evident. Moreover, at the intersection of two arches we see a special zone of attraction. Drawing our attention to these compositional center, the picture represents a loup directing us to the self-immersion of the character. The seine in ordinary life is used for fishing but here, in the context of this work, it is considered as a trap for us: it catches our attention envolving us into the process of meditation and conversation. Why there is such a great degree of concentration? From ancient times Kets lied emphasis on fishing what is confirmed by different researches on rituals in which people call the river "Foremother" and ask her to get free from the ice. Despite the fact that Russian people taught Kets how to catch fish with seines (the same as cloth made from bought textiles, guns and blockhouses) and also despite social and economic problems of that indigenous people, we can notice that the Kets always adhered to pagan attitude to the world. D. Karatanov depicted quite a valuable sacral space where we see not only a process of fixing but also the process of conversation between the nature and this fisherman (Fig. 11).

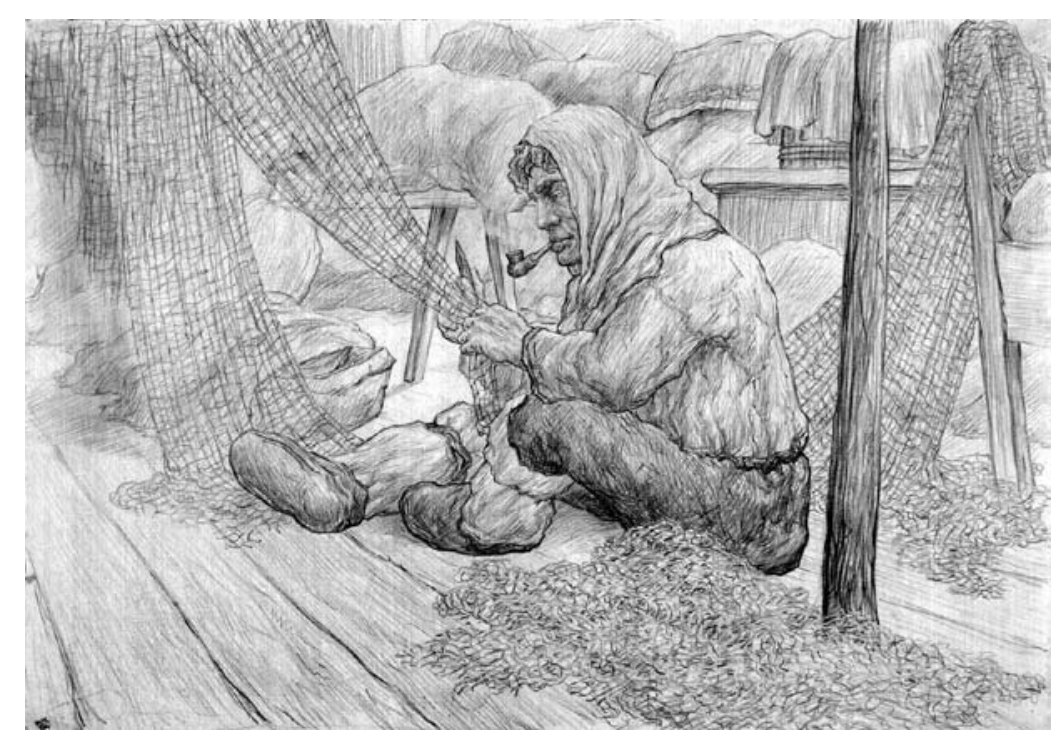

Fig. 11. Repairing the Seine. Inside the izba. 1928. Cartoon. Pencil. 35X50. Vasily Surikov's Art Museum, Krasnoyarsk 
This is another example of drawings of those times telling us about hardworking fishermen among the Kets. The piece of art is featured by an interesting method of composition and the art space decision. The drawer uses embowed lines creating a net and a figure of a sitting Ket in the very center of it. A virtual up-end arc resembles a cover on his head representing a humility before the world and willingness to relationship with the heaven and the earth. Embowed lines of his hands and fishing nets are compositional rising arcs similar to the "bowl of chaotic water".

This work is similar to the one mentioned above in many respects. Nevertheless, thanks to its horizontal format, there is a focus on a dish-shaped form of composition that leads us to the idea of a "kettle": according to recent researches concerning Kets folklore it is connected with a symbolic pleading for a child. There is also a ritual of kettle swaying which means, for example, a wish to be out of "extra animal blood" after their hunting. Kettle is a symbol of sacrifice and its presence in myths and ceremonies can be explained by the necessity of being forgiven, goodwill from nature ghosts or a wish to recover the connection between people and the universe. Thus, the uncertainity in lines and strokes lied in the composition created by such a sensitive artist who wants to understand and express feeling of indigenous peoples, is explained.

When we turn to Ostyaks folklore collected by D. Karatanov during his expeditions, we find out that there is almost no egoism or pride inside tellers. They have a habit of non-resistance to the course of nature: the absence of literacy is explained by the fact that it was eaten by a moose. Ostyaks folklore teaches us how to accept death of other people since after the death they have a better life and care after relatives there. There is also a number of myths telling us about a young girl who is lost in the water but then got married with a merman and in order to calm her relatives she comes with the husband and promise her parents to help.

In the drawing "Repairing the Seine. Inside the izba" that dialectical feature is showed: on the one hand there is a sort of loop captivating the character who holds the net in his hands; on the other hand there is the "kettle" of a bowl of sacrifice to entreat the ghost of the water. The trap regarded a as an example of human finesse, bears to that motive of sacrifice offering. There is a beating combination of some individual needs and ritual common actions aimed at the world safety. D. Karatanov shows some intellectual distance in relationship with the character: there is a secret impermission to depict the character too close. Each of them is just a representative from their indigenous people (Fig. 12).

The picture represents one of the most complete works by D. Karatanov. There is quite an intensive composition, explicating apotheosis of relationship between men and the nature and clearly represent the worldview of the whole humanity. A many-figured scene is artfully built: it begins with a clear semantic center represented on the front and formed by rounded positions of three fishermen attracted by a big and especially valuable fish called taimen. At the same time virtual are drawn concentrically around the catch: slowly widening they make a kind of vibration similar to those which we see in the water after a stone. Circles catches far standing fishermen taking them into that atmosphere of a common excitement. Through other fishermen stand far from the center they also play an important role in general inside solidarity and well-being. Positions of these characters in front of the fine catch establish a sacral center of the humanity, its adoration of the nature which gives them a part of itself (Fig. 13). 


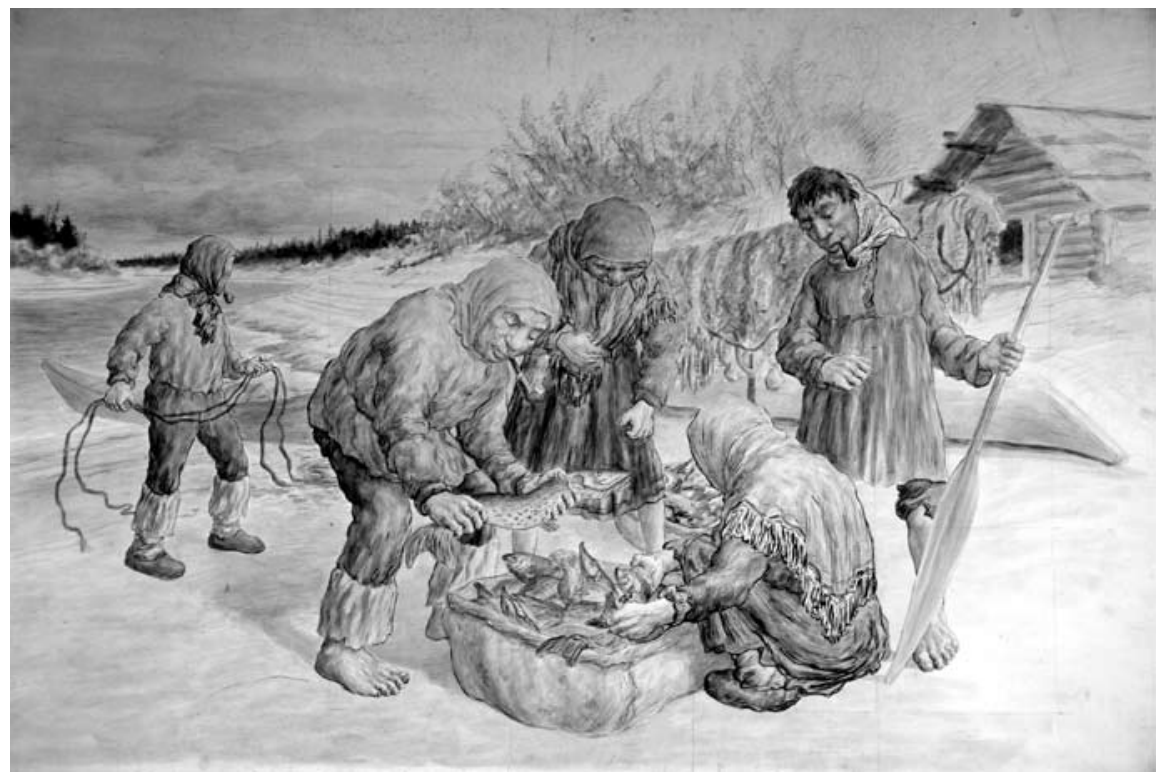

Fig. 12. Fine Fish Catch. 1928. Cartoon. Pencil. Watercolour. 67X100 sm. Krasnoyarsk Regional Museum

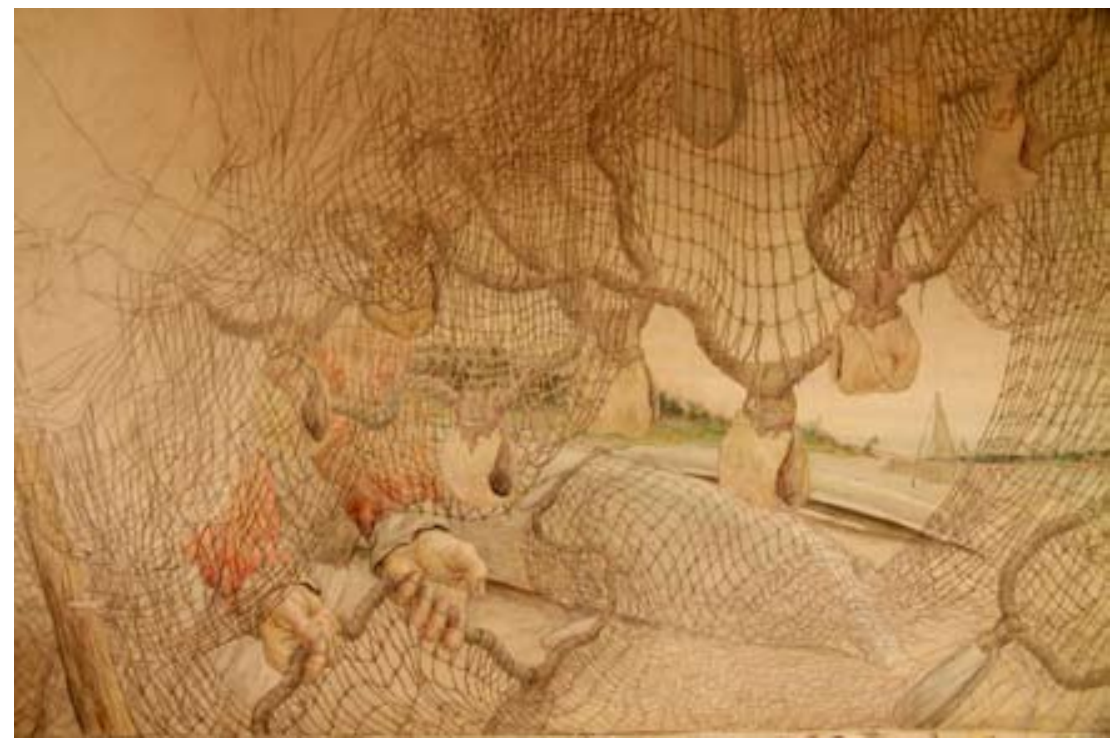

Fig. 13. Nets. (Nets and hands). 1928. Cartoon. Pencil. Colour pencil. 67X100,3 Krasnoyarsk Regional Museum

In this picture we also distinguish a rhythmic chain combination of figures which creates two sinewaves: crossing wavy lines which in this particular case takes the idea of trepidity and energetic exchange between the depicted characters away. The river and fishing theme evoke corresponded attitude to read this composition of movement. The intergrowth of nature and culture depicted in the "ornament" of the living, a natural rhythm of relationship between a person and gods - all these things are a motive for the net based on intercrossing of vertical and horizontal lines. In this picture a chain of Kets fishermen resembles that virtual 
network: relationship and embracement between people and the universe.

This graphic picture might well be called as a top work of the whole series. Here, the artist in a skillful way put himself and the recipient at the position inside the net, i.e. a human soul eager to see the life of Kets from the very center is caught by the net. Fishing nets, fishermen's hands, banks and boats - all these things were chose to laconically represent the most important detail of the rhythmic visual melody taking one's soul by the beat of falling floats and a wavy edge of the fishing net. A soul-taking effect literally and figuratively represent an extreme part of the whole Ostyak series. Such methods as contrast between landscape distance and front place, a close-up view for hands and nets, ambivalence of the pore net structure (as the net is a pure structure of intercrossing lines as well as something opened and airy to a maximum degree) play an important role here. He sky seen though the net creates a beat between "distanced" and "close" - the rhythm of an intensive breathing which occurs when one feels his death and the universe.

\section{Conclusion}

The problem of a slow extinction of indigenous people was in constant interest of the artist but it was determined not only by tragic or dramatic motives. In works by D. Karatanov an escape from that crisis state, from a dynamic balancing between life and death, civilization and nature is seen in a rhythmic principle transforming the routine into the cultural living of indigenous Siberian peoples. Rhythms presented in image of his characters are a sort of praying, a message to the heaven from the whole humanity that inspires Christianized Ostyak people who do not refuse pagan life,the artist himself born in the Christian family and the humanity constantly searching for ways to establish relationship with the Universe.

\section{Acknowledgments}

The author acknowledges directors and employees of the Krasnoyarsk Regional Museum and Vasily Surikov's Art Museum for a given opportunity to work with archives. Special gratitude for supporting and resource providing is given to L.N. Zhukovskaya and N.G. Istomina.

\section{References}

1. Chrissidis, N. (2013). Visual anthropology of the empire, or «Seeing Russian is not given to everyone». Russian review, 72 (2), 303-304. doi: 10.1111/russ.10693

2. Crate, S.A., Fedorov, A.N. (2013). A Methodological Model for Exchanging Local and Scientific Climate Change Knowledge in Northeastern Siberia. Arctic, 66 (3), 338-350.

3. Donahoe, B. (2011). On the creation of indigenous subjects in the Russian Federation. Citizenship studies, 15 (3-4), 397-417. doi: 10.1080/13621025.2011.564803

4. Dudarev, A.A., Dorofeyev, V. M., Dushkina, E.V., Alloyarov, P.R..; Chupakhin, V.S., Sladkova, Y.N., Kolesnikova, T.A., Fridman, K.B.; Nilsson, L.M., Evengard, B. (2013). Food and water security issues in Russia III: food- and waterborne diseases in the Russian Arctic, Siberia and the Far East, 20002011, International journal of circumpolar health, 72, No: 21856. doi: 10.3402/ijch.v72i0.21856

5. Duggan, A.T., Whitten, M., Wiebe, V., Crawford, M.; Butthof, A. Spitsyn, V., Makarov, S., Novgorodov, I. Osakovsky, V., Pakendorf, B. (2013). Investigating the Prehistory of Tungusic Peoples of Siberia and the Amur-Ussuri Region with Complete mtDNA Genome Sequences and Y-chromosomal Markers. Plos one, 8 (12). No: UNSP e83570, 2013. doi: 10.1371/journal.pone.0083570.

6. Fedorova, S.A., Reidla, M., Metspalu, E., Metspalu, M., Rootsi, S., Tambets, K., Trofimova, N., Zhadanov, S.I., Kashani, B.H., Olivieri, A. (2013). Autosomal and uniparental portraits of the native 
populations of Sakha (Yakutia): implications for the peopling of Northeast Eurasia. BMC evolutionary biology, 13. No: 127, 2013. doi: 10.1186/1471-2148-13-127

7. Forbes, B. C. (2013). Cultural Resilience of Social-ecological Systems in the Nenets and Yamal-Nenets Autonomous Okrugs, Russia: A Focus on Reindeer Nomads of the Tundra. Ecology and society, 18 (4), No: 36. doi: 10.5751/ES-05791-180436

8. Gorshkov, S. Evseeva, L., Mochalova, O., Touchart, L., Ballais, J. L.; Simone, Y. (2013). Environment, economy and community of the upper Angara and middle Yenisei regions: impact of climate change and water reservoir cascades built on the Angara and Yenisei rivers. Polar record, 49 (250), 254-260. doi: 10.1017/S0032247413000107

9. Happel, J. (2013). Surrounded by Vermin and Savages. Travellers to Siberia in the 18th Century. Jahrbucher fur geschichte osteuropas, 61 (1), 1-25.

10. Kay, R. (2011) (Un)caring communities: Processes of marginalisation and access to formal and informal care and assistance in rural Russia. Journal of rural studies, 27 (1), 45-53. doi: 10.1016/j. jrurstud.2010.11.002

11. Lavrillier, A. (2013) Climate change among nomadic and settled Tungus of Siberia: continuity and changes in economic and ritual relationships with the natural environment. Polar record, 49 (250), 260-271. doi: 10.1017/S0032247413000284

12. Lebedev, I. A. (2011) Prevalence and risk factor structure of cerebral stroke in people of the Khanty-Mansi autonomous okrug. Zhurnal nevrologii i psikhiatrii imeni S S Korsakova, 111 (12), 7076.

13. Leete, A., Vallikivi, L. (2011) Adapting christianity on the siberian edge during the early soviet period. Folklore, 49, 131-146.

14. Maj, E. (2012). Internationalisation with the use of Arctic indigeneity: the case of the Republic of Sakha (Yakutia), Russia. Polar record, 48 (246), 210-214. doi: 10.1017/S003224741100060X

15. Novik, E.S. Modes of evidentiality and types of narrators in the archaic folklore of peoples of Siberia. Russian literature, 71 (3-4), 401-419. doi: 10.1016/j.ruslit.2012.06.010

16. Petrenya, N., Dobrodeeva, L., Brustad, M., Bichkaeva, F., Menshikova, E., Lutfalieva, G., Poletaeva, A., Repina, V., Cooper, M., Odland, J.O. (2011) Fish consumption and socio-economic factors among residents of Arkhangelsk city and the rural Nenets autonomous area. International journal of circumpolar health, 70 (1), 45-58.

17. Pitulko, V.V., Pavlova, E.Y., Nikolskiy, P.A., Ivanova, V.V. (2012) The oldest art of the Eurasian Arctic: personal ornaments and symbolic objects from Yana RHS, Arctic Siberia. Antiquity , 85 (333), 649-659.

18. Regueiro, M., Alvarez, J., Rowold, D., Herrera, R.J. (2013) On the Origins, Rapid Expansion and Genetic Diversity of Native Americans From Hunting-Gatherers to Agriculturalists. American journal of physical anthropology, 150 (3), 333-348. doi: 10.1002/ajpa.22207

19. Toulouze, E. (2011). Movement and Enlightenment in the Russian North. Folklore, 49, $97-$ 112.

20. Znamenski, A.A (1999). Vague sense of belonging to the Russian empire": The reindeer Chukchi's status in nineteenth century northeastern Siberia. Arctic anthropology, 36 (1-2), 19-36.

21. Abisova A.A. Dmitry Innokentyevich Karatanov, booklet, 1999.

22. Abisova A.A. (2003). Signer of Siberia. 100 famous citizens of Krasnoyarsk. Pp. 143-147. 
23. Abisova A.A., Paramonova V.I. (1989). Dmitry Innokentyevich Karatanov. The century of self-sacrifice. Pp. 58-64.

24. Alekseenko E.A. Introduction. Myths, legends and fairytales of Kets, Moscow, 2001, Pp. 1- 22.

25. Alekseenko E.A. A concept of kettle in narrative and traditions of Kets. Myth, symbol, ritual. Peoples of the Siberian Region. Moscow, 2008, pp. 68-72.

26. Amosov A.Y., Koptseva N.P., Libakova N.M., Reznikova K.V., Sertakova K.V., Pimenova N.N., Kistova A.V. [and others], Indigences peoples of the North and Siberia in the context of global transformations (a case study of the Krasnoyarsk Territory). Part I. Conceptual and methodological basis of the research. Ethnocultural dynamics of indigenous peoples in the Krasnoyarsk Territory. Ex.editor N.P. Koptseva, Krasnoyarsk: Siberian Federal University. 2012, 640 p.

27. Anuchin V.I. In a country of dark days and wight nights. Petrograd: P. P. Soykin, 1916, 32 p.

28. Bakhova N.A., Bukharov A.V., Viktoruk Y.A., Ilbeykina M.I. New future of Siberia: expectations, challenges and solutions: monograph. Endorsed by O.A. Karlova, N.P. Koptseva. Krasnoyarsk: Siberian Federal University. 2013.

29. D.I. Karatanov's works exhibition: to the $85^{\text {th }}$ anniversary of the Honored Artist of the RSFSR: catalog, Krasnoyarsk, 1959. - 8 p.

30. Golovnev A.V. (1997). Figure symbols of the Khants. Peoples of Siberia. History and culture. Pp. 82-89.

31. Davydenko I.M. Great artist: [words about V.I. Surikov] Krasnoyarsk and its citizens: [essays on the history of the city], Krasnoyarsk, 1978, Pp. 87-93.

32. Davydenko I.M. Artists of Krasnoyarks. Krasnoyarsk, 1978, 180 Pp.

33. Davydenko I.M. Generous talent: memories about he Honored Artist of the RSFSR A.P. Lekarenko. Krasnoyarsk: Krasnoyarsk book publisher, 1985, 93 p.

34. Yevmenova L.N. The culture of russian settlers in the Territories near the Yenisey: monograph. Krasnoyarsk: Siberian Federal University, 2007, 232 p.

35. Provinces near the Yenisey: History. Archeology. Geography. Ethnography. Philology: Anthology. Part I. Krasnoyarsk: Krasnoyarsk State Pedagogical University named after V. P. Astafyev, 2004, 112p.

36. Encyclopedia of the Yenisey Regions. $1998.735 \mathrm{p}$

37. Zhukovsky V.I. (2010) Character and features of a dialog between the recipient and art works. Art education, Pp. 229-235.

38. Zhukovsky V.I. Art studies. Saint-Petersburg, 2011, 495 p.

39. Zamaraeva Yu.S. (2010). Actual studies of relationship between migrants and host areas in the modern philosophy. Science and modern times, 5-3, p. 96-100.

40. History of the Krasnoyarsk Territory. Complied by A.M. Anufriev [and others]; Ed. A.P. Stateynov [and others]. V. 1: Culture. Krasnoyarsk: Bukva, 2008, 546 p.

41. History of the Krasnoyarsk Territory. V. 1: Culture. Krasnoyarsk: Bukva, 2008, 546 p.

42. Kalinina S.A. (2011) History of Krasnoyarsk branch of the Union of Artist of the USSR in 1940s based of GAKK documents, Youth Scientific Conference: Materials of VI Rissia-wide scientific and research conference for students, candidates and young scientists [Эonline resource].- - Available at: http://conf.sfu-kras.ru/sites/mn2010/section7.html, свободный. 
43. Dmitry Innokentyevich Karatanov, artist. My Krasnoyarsk - national encyclopedia. Available at: http://region.krasu.ru/node/271 (accessed 8 February 2014)

44. Karnaukhova L.L. (2000). Dmitry Innokentyevich Karatanov. Men of museums. Available $a t$ : http://www.kkkm.ru/(accessed 8 February 2014)

45. Kirko V.I., Verkhovets S.V., Keush A.V. (2010). The role of federal universities in organization of innovative regional structure (through the example of Siberian Federal University). Innovations, (10), p. 60-64.

46. Kirko V.I., Zakharova K.N. (2013). Traditional agriculture: lifestyle that saves the nation. Arctics and the North (12), p. 24-31.

47. Kiselev Ye. (2011) Arists and ethnographers of the Krasnoyarsk Territory: Field book. Natural resources of the Krasnoyarsk Territory, (9), Pp. 112-115

48. Kistova A.V. (2013). Methodological importance of "understanding hermeneutics" by Wilhelm Dilthey for social and philosophic study of modern social and cultural phenomena. Modern problems in science and education, 3, Pp. 450.

49. Koptseva N.P. Luzan V.S. State cultural policy in Siberian Federal District monograph. Krasnoyarsk: Siberian Federal University, 2012.

50. Koptseva N.P. Introduction in alithiology Krasnoyarsk: Krasnoyarsk state University, 2002.

51. Koptseva N.P., Sertakova Ye. A., Ilbeykina M.I., Zamarova Yu.S., Libakova N.M., Luzan V.S. Indigences peoples of the North in the context of global transformations: monograph / Ed. by N.P. Koptseva Saint-Petersburg: Eidos, 2011, 174 p.

52. Koptseva N.P., Philosophy and culture:consonance in cognitive space // Science essays at the Faculty of Arts and Cultural Science . - Part I. - Krasnoyarsk, 2000.

53. Koptseva N.P., (2007). Integration of humanitarian education in Siberian Federal University. Higher education of today, 4, 6-8.

54. Koptseva N.P., (2007). The theory and practice of innovative curriculum on esthetics disciplines. Higher education of today, 12, 9-13.

55. Koptseva N.P., (2012). Cultural basis for national identity formation in Siberian Regions of the Russian Federation. The Reporterof Volgograd State University. Part 7. Philosophy, sociology and social technologies 3, 11-15.

56. Koptseva N.P. (2012). Methodological opportunities in social anthropology for modern cultural study. Philosophy and culture, 10, 9 -18.

57. Koptseva N.P (2012). Problems of methodology in modern cultural study: alternatives of classical British social anthropology. Human and social sciences, 4, 89-104.

58. Koptseva N.P (2013). Applied cultural research on crosscultural communication: focus groups, personal interview, surveys and expert evaluations (at the study case of the Krasnoyarsk Territory). Modern problems in science and education, 3, 410-410.

59. Koptseva N.P., Libakova N.M.,(2013). Effectiveness of a gender method in human study. Modern problems in science and education.- 2013. - №1.

60. Koptseva N.P., Nevolko N.N. (2012). Visualization of folk traditions in paintings and graphics of the Khakas. Art and education, 1, 27.

61. Krivinogov V.P. Peoples of the Taimyr (modern ethnic processes), Krasnoyarsk: Krasnoyarsk State Pedagogical University named after V. P. Astafyev, 2001. 
62. Krivinogov V.P. Peoples of the Taimyr in the beginning of XXI century, Krasnoyarsk: Krasnoyarsk State Pedagogical University named after V. P. Astafyev, 2007.

63. Libakova N.M. (2011). Modification of gender forms in the Russian culture in the end of XIX and in the beginning of XXI centuries: thesis ... Cand.of philosophical science: 24.00.01; [Defended at: the Yaroslav-the-Wise Novgorod State University ].- Krasnoyarsk, 155 p.

64. Lisovsky N.V. The artist of Siberia. D.I. Karatanov. Krasnoyarsk, 1974, 147 p.

65. Lomanova T.M. Artists of Krasnoyarsk. Krasnoyarsk, 2007, 317 p.

66. Luzan V.S. Social and philosophial analysis of the dynamic of state cultural policy in the Russian Federation: thesis ... Cand.of philosophical science. Krasnoyarsk, 2011, 170 p.

67. Luzan V.S. (2013) Contexts for understanding intellectual leisure in modern study. The reporter of the Krasnoyarsk State Pedagogical University named after V. P. Astafyev, 4 (26), . 175-178.

68. Meshalkin P.N. (1999) Siberian Singer. Yenisey, 216. 140-144.

69. Meshalkin P.N. The Yenisey province at world exhibitions. Krasnoyarsk: Klaretianum, 1997, $36 \mathrm{p}$.

70. Moskalyuk M.V. All that in heart. Krasnoyarsk Artists of yesterday, today and tomorrow. Krasnoyarsk, Polikor, 2010, 286 p.

71. Myltygasheva L. (2004). The master and his students. Krasnoyarsky Rabochy (30), Pp. 3.

72. Niyachenko T.S. (2004). Dmitry Karatanov. New Time: Social and political paper of Bolshemurtinsky Region. Pp. 7.

73. Geniuses. Artists of Krasnoyarsk in XIX-XX centuries : essays. 1998, $184 \mathrm{p}$.

74. Pavlov N.L. Altar. Stupa. Temple. Moscow, 2001, 368 p.

75. Historical and cultural monuments in the Krasnoyarsk Territory. Collected by.: G.F. Bykonya, chief ed.: G.L. Ruksha. Part. 2 Krasnoyarsk: Krasnoyarsk State Pedagogical University named after V. P. Astafyev, $1992-271$ p.

76. Historical and cultural monuments in the Krasnoyarsk Territory. Part 1. Krasnoyarsk: Book publisher, 1989, $399 \mathrm{p}$.

77. Historical and cultural monuments in the Krasnoyarsk Territory. Part 4. V. 1, 1997, 349 p.

78. Historical and cultural monuments in the Krasnoyarsk Territory. Collected by. : G.F. Bykonya, ; Krasnoyarsk State Pedagogical University named after V. P. Astafyev, 1995, Part. 3 - 432p.

79. Pozdnykova O.A., Reznikova K.V. (2013). Features of participants in artistic cinema communication. Modern problems in science and education, 4, P. 385.

80. Reznikova K.V. (2013). Importance of cinema for national identity formation. Modern problems in science and education, 3, P. 416.

81. Reznikova K.V. Social construction of national identity in the Russian Federation: abstract from a thesis ... Cand.of philosophical science: 09.00.11 [[Defended at: Siberian Federal University].Krasnoyarsk, 2012, 20 p.

82. Ryannel T.V. The artist Karatanov, Krasnoyarsk, 1948, 22 p.

83. Semyonova A.A., Gerasimova A.A. (2013). Features of S. Anufriev's artistic approaches. Modern problems in science and education, 2, P. 542.

84. Semyonova A.A. Modifications of the Old Russian concept "state" in the Russian culture of XXI century: thesis ... Cand.of philosophical science: 24.00.01 [Defended at: The Yaroslav-the-Wise Novgorod State University ]- Krasnoyarsk 2009. 198 p. 
85. Semyonova A.A. (2012). Visual culture of modernized society, The Reporter of Volgograd State University. Part 7. Philosophy, sociology and social technologies, 3, Pp. 141-149.

86. Serikova T.Yu. (2011) Influence of national cultural situation of 1960-80s on formation of visual image of a contemporary in Siberian art tradition at the study case of works by T.V. Ryannelya, A.M. Znak, M.S. Ombysh-Kuznetsov, G.I. Kichigin. Youth Scientific Conference: Materials of VII Rissia-wide scientific and research conference for students, candidates and young scientists dedicated to the $50^{\text {th }}$ anniversary of the first human's flight to the space [Online resource]. Available at: http://conf.sfu-kras.ru/sites/mn2011/section05.html, free. (accessed 8 February 2014)

87. Sertakova Ye. A. (2010). Functional art works in the Internet. Science and modern times 3-1, Pp. 64-68.

88. Sertakova Ye. A. (2012). Cultural geography by A. Lefer in the context of human study of the urban space. Theory and practice of social development, 3, Pp. 24-26.

89. Sertakova Ye. A.. (2013). Analysis of "city" in classical conceptions of foreign scientists, Modern problems in science and education, 4, P. 381.

90. Dictionary of fishermen and hunters of Northern Angara regions: reference book,1994, $119 \mathrm{p}$.

91. Smolina M.G., Soshenko M.V. (2013). Features of works by Olga Ryabvol in russian ceramics tradition. Modern problems in science and education, 2. Available at: http://www.science-education. ru/108-8619 (accessed 8 February 2014).

92. Smolina M.G. (2013). Relationship between recipients and the art space in D. Karatanov's works. Siberian hunter lodge, available at: http://zaimka.ru/smolina-karatanov/ (accessed 8 February 2014)

93. Smolina M.G. (2011). Comic means in illustrations by Marc Chagall to "Dead Souls" by N.V. Gogol (1923-1927), Polignozis, 3-4 (42). Available at: http://www.polygnozis.ru/default. asp?num=6\&num2 $=577$ (accessed 8 February 2014).

94. Smolina M.G., Kushnareva A.A. (2013). Alliance between Siberian and Oriental art: results of III International Music Festival of Asia-Pacific Region (2012). Modern problems in science and education, 2013 (6). Available at: www.science-education.ru/113-11127 ( accessed: 11.02.2014).

95. Development of free touristic territory in settlements of indigenous peoples as one of the ways to solve ethnic problems of the Russian North: (reports of the State Natural Biosphere Reserve "Taimyrsky")/ B.V. Pestryakov ; State Natural Biosphere Reserve "Taimyrsky", Peter the Great Academy of Arts and Science. Center for problems of the Russian North, Arctics and Antarctica. Part 2 Khatanga: Polikom, 2001, 13 p.

96. Tarabukin N.M. (1973). Semantics of diagonal compositions in art. Works on semiotic systems, 6, Moscow, pp. 472-481.

97. Filippova S. (2005). Successor of Surikov and Kuindzhi. The Urban News (100), P. 2

98. Artists of the Krasnoyarsk Territory, Б. м., 1991, 215 p.

99. Artists of the Krasnoyarsk Territory: Painting; Graphics; Sculpture; Applied and Decorative Arts; Art Designing. Moscow: Soviet Artists, 1991 - 216 p.

100. Chebodaeva M.P. Khakasia in V. Surikov's works. Saint-Petersburg, 2011, 84 p.

101. Chmykhalo B.A. (2004). The master. The Urban News (23), P. 5.

102. Best people of Krasnoyarsk at the cusp between two millenniums: [historic essay] : catalog. Krasnoyarsk: Siberia, 2000, 159 p. 
103. Peoples of Siberia. History and modern times: summary of the Scientific and Research Conference dedicated to $60^{\text {th }}$ anniversary of the Krasnoyarsk Region, November and December, 1994. Б.м., 1994, 288 p.

104. Yurii Khugonogov. [Painting]: [album] Khudonogova, Yelena Yurievna, Pokrovskaya N.V., Abisova A.A. Б.м., 1999, 126 p.

105. Yavorsky A.L. (2002). D.I. Karatanov. Works and people. Available at: http://www.stolby.ru/ Mat/Yavorsky/GAKK/226/Karatanov/001.asp (accessed 8 February 2014)

\section{Образ коренного народа Сибири}

в творчестве Д.И. Каратанова

М.Г. Смолина

Сибирский федеральный университет Россия, 660041, Красноярск, пр. Свободный, 79

Предметом исследования статьи служит отражение образа коренного северного малочисленного народа Сибири (кетов, так называемых остяков) в творчестве Дмитрия Иннокентьевича Каратанова. Цель работы достигается посредством изучения своеобразия черт творчества красноярского художника в сфере портретов остяков, пейзажей Сибири, бытовых многофигурных сиен. Основные методы исследования - это структурносемиотический анализ произведения культуры, выявление и анализ основных композиционных особенностей, разбор диалектики имманационного и эманационного начал художественного образа. В результате анализа репрезентантов остяичкой серии рисунков Каратанова определена особая роль идеи труда кетских рыболовов как прамолитвы, обращенной к природе как дарительнице благостной жизни. Области применения результатов: искусство Красноярского края, история и культура Сибири, исследования по национально-культурной идентичности.

Ключевые слова: Каратанов, Суриков, рисунки, остяки, кеты, труд, рыболовство, Север, Сибирь, Красноярск, композиция, эманация, коренные малочисленные народы, этнография, экспедиция.

Научная специиальность: 17.00.00 - искусствоведение. 